\title{
New lichenized fungi for Russia from Dagestan (East Caucasus)
}

\author{
Aziz B. Ismailov ${ }^{1}$, Gennadii P. Urbanavichus ${ }^{2} \&$ Jan Vondrak $^{3,4}$ \\ ${ }^{1}$ Mountain Botanical Garden, Dagestan Scientific Center of RAS, M. Gadjieva str. 45, 367000 Makhachkala, \\ Republic of Dagestan, Russia.E-mail: i.aziz@mail.ru \\ ${ }^{2}$ Institute of North Industrial Ecology Problems, Federal Research Centre "Kola Science Centre of RAS", \\ Akademgorodok 14a, 184209 Apatity, Murmansk region, Russia. E-mail: g.urban@mail.ru \\ ${ }^{3}$ Institute of Botany, Academy of Sciences of the Czech Republic, Zámek 1, 25243 Průhonice, Czech Republic \\ ${ }^{4}$ Department of Botany, Faculty of Biological Sciences, University of South Bohemia, Branišovska 31, \\ 37005 České Budějovice, Czech Republic. E-mail: j.vondrak@seznam.cz
}

\begin{abstract}
Three lichen species (Anaptychia elbursiana, A. roemeri and Megaspora rimisorediata) are reported for the first time for Russia from Dagestan. Anaptychia elbursiana is reported for the first time from North Caucasus, and Anaptychia roemeri and Megaspora rimisorediata from the Greater Caucasus. The characteristic features of the species and information on their morphology, anatomy, ecology and world distribution are given. Differences from similar species are discussed.
\end{abstract}

Keywords: lichens, new records, floristic studies, Dagestan, Caucasus, Russia

\section{INTRODUCTION}

According to the Floristic Division of the World (Takhtajan, 1986), Dagestan is located on the border between the Caucasian (Circumboreal Region) and the Turanian (Irano-Turanian Region) floristic provinces, or, more broadly, the Boreal and the Ancient Mediterranean floristic subkingdoms. The Caucasian province is more humid and the Turanian more arid. Due to the diverse geomorphology and wide altitudinal range (from -26 to $4466 \mathrm{~m}$ a.s.1.), Dagestan harbours a species-rich mosaic of vegetation types ranging from xerothermic to alpine (e.g., montane dry pine forests, mesophytic deciduous forests, steppes, lowland semi-deserts and subnival stony deserts). This is reflected in a substantial lichen diversity.

The present paper provides further information on the lichen flora of Dagestan, the Caucasus Mountains, and Russia. Currently about 850 lichen species are known in the Republic of Dagestan.

\section{STUDY AREA}

The Republic of Dagestan with a total area of $50,300 \mathrm{~km}^{2}$ is situated on the Eastern part of the North Caucasus, on the western shore of the Caspian Sea (Fig. 1). The territory of the republic has a rather continental climate. The average annual relative humidity is $60 \%$. The average annual precipitation is $600 \mathrm{~mm}$, rang- ing between $200 \mathrm{~mm}$ and $1000 \mathrm{~mm}$ in different altitude zones. The northern part of Dagestan is drier. It includes the Tersko-Kumskaya plain with semidesert vegetation. The southern part is mountainous and more humid and covered by the Greater Caucasus Mountains with the highest peak at Mount Bazardyuzi - $4466 \mathrm{~m}$ (Akayev et al., 1996).

Lichens were collected by the authors in four localities situated in the foothills (loc. 1) and in the mountainous part of Dagestan (locs 2-4; Fig. 1 ). The $1^{\text {st }}$ locality is a dry steppe in a gully at about $100 \mathrm{~m}$ altitude with calcareous bedrock.

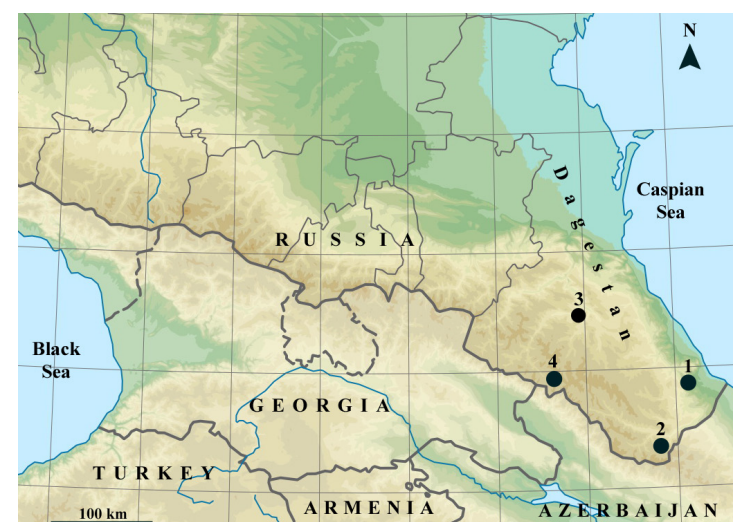

Fig. 1. Location of Dagestan in the Caucasus and of the sampling sites (1-4). 
The $2^{\text {nd }}$ is Mount Shalbuzdag, a limestone mountain with arid climate and the highest point at $4142 \mathrm{~m}$. The $3^{\text {rd }}$ locality is a montane pine forest on the Gunib Plateau. The $4^{\text {th }}$ locality is on the spurs of the Caucasus ridge. It is an open woodland with Quercus macranthera scattered on a steep east slope above the left bank of the Dzhoakhor River. For more details of the localities see "Specimens examined".

\section{MATERIAL AND METHODS}

The specimens were collected by the authors in July 2015 (locs 1 \& 3) and July 2018 (locs 2 \& 4).

Morphological and microscopic characters were examined by standard microscopic techniques (LOMO Mikmed-6 and MSP-2) and chemical spot tests commonly used for the identification of lichenized fungi were performed. The taxa are listed in alphabetical order, followed by descriptions of the Dagestan specimens, locality and world distribution. Specimens are deposited in the Herbarium of the Mountain Botanical Garden (DAG) and the Institute of Botany of the Czech Academy of Sciences (PRA) or in the private herbarium of G. P. Urbanavichus (Anaptychia elbursiana).

\section{THE SPECIES}

Anaptychia elbursiana (Szatala) Poelt, Nova Hedwigia 12: 132. 1966. - Physcia grisea var. elbursiana Szatala, Ann. Naturhist. Mus. Wien 50: 532. 1939. - Physcia elbursiana (Szatala) Szatala, Ann. Hist.-Nat. Mus. Natl. Hung. 8: 152. 1957. (Fig. 2).

Thallus foliose, $3-4 \mathrm{~cm}$ in diam., appressed, white to gray, usually pruinose, sorediate. Lobes mostly irregularly flabellate, contiguous to overlapping, 0.8-1(2) $\mathrm{mm}$ wide, flat at the tips but becoming convex towards the lobe bases, with rather coarse, but sparse cortical hairs near the lobe ends. Soralia primarily marginal and terminal on lateral lobes, labriform, sometimes with scattered punctiform laminal soralia forming in older thallus regions; soredia coarsely granular, often becoming distinctly darkened, sometimes almost black. Upper cortex prosoplectenchymatous. Medulla white. Lower surface almost white on the lobe ends, becoming pale to dark tan towards the lobe bases, without well-developed cortex; rhizines scattered, simple to irregularly

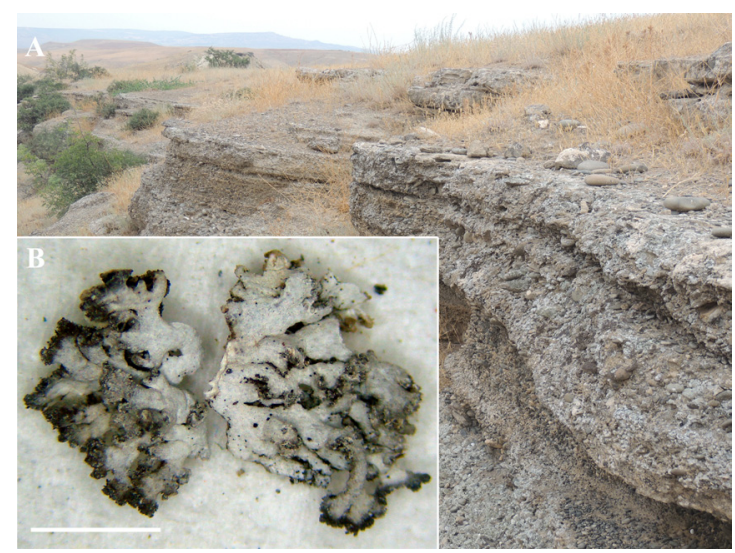

Fig. 2. Anaptychia elbursiana. A - habitat; B thallus (scale bar $0.5 \mathrm{~cm}$ ).

furcate, concolorous with the lower surface. Apothecia in the examined specimen absent.

Spot tests: cortex, medulla and lower surface $\mathrm{K}-, \mathrm{C}-, \mathrm{KC}-, \mathrm{Pd}-$.

This species is most closely related to A. desertorum (Rupr.) Poelt, which lacks soredia and isidia, and usually produces apothecia.

Anaptychia elbursiana is a xerophilous species described from the central part of the Elburz Mountains in northern Iran (Szatala, 1940). The species is reported from arid regions of western North America (Esslinger, 2007) and Asia (Turkey, Azerbaijan, Iran, Turkmenistan, Tajikistan, Afghanistan, Pakistan, Mongolia) mostly at low and middle elevations not higher than $3000 \mathrm{~m}$ above sea level (Pišút, 1978; Steiner \& Poelt, 1986; Huneck et al., 1987; Kudratov \& Mayrhofer, 2002; Seaward et al., 2004; Urbanavichus, 2008; Candan, 2016). It is also reported from the Canary Islands, Tenerife (Hernández-Padrón \& Pérez-Vargas, 2010).

New to Russia and the North Caucasus. The nearest known locality is about $215 \mathrm{~km} \mathrm{SE}$ in the Gobustan Nature Reserve in the southwestern part of the Absheron Peninsula in Azerbaijan (Alverdiyeva \& Aghayeva, 2015).

Specimen examined: Russia, Eastern Caucasus, Republic of Dagestan, Derbentskiy district (loc. 1), right

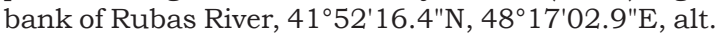
$85 \mathrm{~m}$, calcareous cliffs on steppe slope, on very thin soil layer over rock, 17.07.2015, leg. G. Urbanavichus (hb. Urbanavichus). 
Anaptychia roemeri Poelt, Mitt. Bot. Staatssamml. München 7: 228 1968. (Fig. 3).

Thallus foliose, lobate, regularly radiated or irregular, $4 \mathrm{~cm}$ in diam., dark gray to dark brown or light-brown in shadow conditions. Lobes $0.35-0.6 \mathrm{~mm}$ wide, raised, with widened, furcate tips, divided into verrucose lobules, with hyaline spines at lobe tips. Upper surface smooth, or scabrous with cracked epinecral layer, pruinose, especially on the tips of the lobes, mostly graybrown. Medulla white with crystals of calcium oxalate. Lower surface bright with simple rhizines. Upper and lower cortex prosoplectenchymatous. Soredia and isidia absent. Apothecia not known.

Spot tests: cortex, medulla and lower surface $\mathrm{K}-, \mathrm{C}-, \mathrm{KC}-, \mathrm{Pd}-$.

Anaptychia roemeri resembles $A$. desertorum but the latter is usually with apothecia and the tips of the lobes are not strongly divided into lobules. A. elbursiana and A. mereschkowskii (Tomin) Kulakov are sorediate species.

First record for Russia and the Greater Caucasus. The nearest location known is in Armenia (ca. $270 \mathrm{~km} \mathrm{SW}$ - Ararat and Vayotz Dzor provinces (Gasparyan \& Sipman, 2016).

The species was described from Afghanistan (Poelt \& Wirth, 1968) and has a restricted distribution in dry-continental areas of Asia, in Armenia, Afghanistan, Iran, Kyrgyzstan, Mongolia and Tajikistan (Poelt \& Wirth 1968; Kudratov \& Mayrhofer, 2002; Seaward et al., 2004; Gasparyan $\&$ Sipman, 2016). Most of specimens were collected from altitudes above $3000 \mathrm{~m}$.

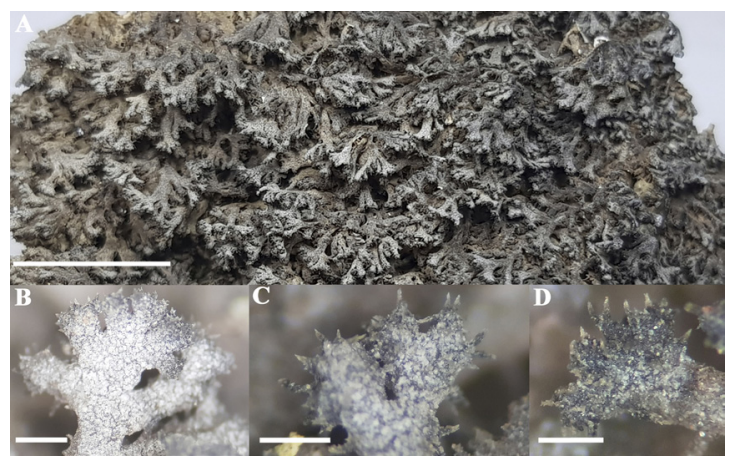

Fig. 3. Anaptychia roemeri. A - thallus (scale bar $1 \mathrm{~cm}$ ); B-D tips of lobes with hyaline spines (scale bars $0.5 \mathrm{~mm}$ ).
Specimen examined: Russia, Eastern Caucasus, Republic of Dagestan, Dokuzparinskiy district (loc. 2),

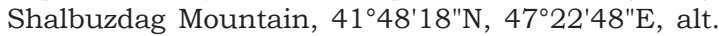
$3100 \mathrm{~m}$, arid habitats among calcareous rocks, on calcareous soil among the mosses on rocks, 12.07.2018, leg. A.B. Ismailov (DAG 1096).

MEgaspora Rimisorediata Valadbeigi \& A. Nordin, Lichenologist 43(4): 287. 2011. (Fig. 4).

A detailed description is given by T. Valadbeigi et al. (2011). It is a sterile sorediate crust easily recognized by the characteristic, wide cracks producing bluish soralia at the sides. The specimen has a pale ochraceous to bluish grey, cracked and sorediate thallus forming a spot $7 \times 4 \mathrm{~cm}$. Cracks are up to $0.25 \mathrm{~mm}$ wide and form a dense net over the thallus (Fig 4C). Cortex paraplectenchymatous with brownish to ochraceous upper part and hyaline lower part. Medulla white. Upper cortex and medulla with crystals of calcium oxalate. Soredia globular, dark bluish green, 45-90 $\mu \mathrm{m}$ in diam., produced on the sides of cracks. Apothecia in the examined specimen not observed.

Spot tests: upper cortex and medulla $\mathrm{K}-, \mathrm{C}-$, $\mathrm{KC}-, \mathrm{Pd}-$.

Another sorediate Megaspora species, M. cretacea Gasparyan, Zakeri \& Aptroot has superficial soredioid granules and lacks sorediate thallus cracks.

New to Russia and the Greater Caucasus. The nearest known locality is about $270 \mathrm{~km} \mathrm{SW}$, in Armenia, Ararat, Vayotz Dzor and Syunik provinces (Gasparyan \& Sipman, 2016).

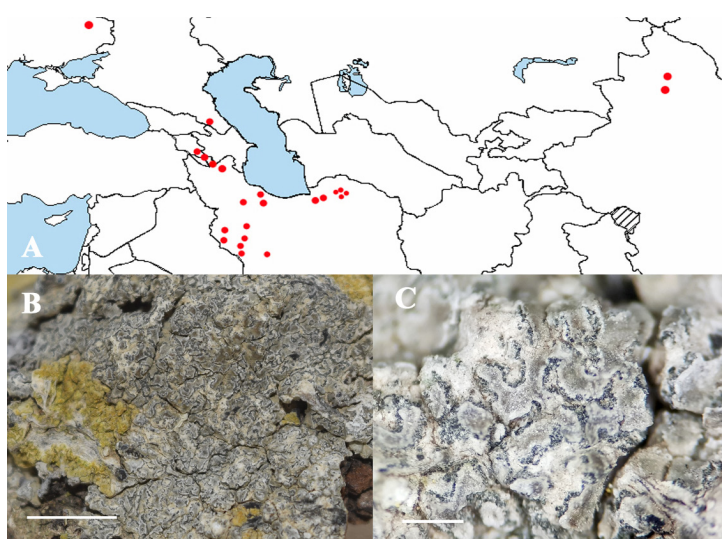

Fig. 4. Megaspora rimisorediata. A - world distribution; B - thallus (scale bar $0.5 \mathrm{~cm}$ ); C - part of thallus (scale bar $0.5 \mathrm{~mm}$ ). 
The species was described from Iran (Valadbeigi et al., 2011) and is widely distributed in eastern Europe - East Ukraine (Moniri et al., 2017) and Asia - Armenia, North Iran, China (Valadbeigi et al., 2011; Gasparyan \& Sipman, 2013; Kondratyuk et al., 2016).

Specimens examined: a) Russia, Eastern Caucasus, Republic of Dagestan, Gunibskiy district (loc. 3), Gunib Plateau, 42 41'47"N, 46²' 12 'E, alt. 1900 m, montane pine forest, on Populus tremula, 18.07.2015, leg. J. Vondrak (PRA 14450); b) Russia, Eastern Caucasus, Republic of Dagestan, Tlyaratinskiy district (loc. 4), at Salda village (spurs of the Caucasus ridge), $41^{\circ} 58^{\prime} 13^{\prime \prime} \mathrm{N}, 46^{\circ} 30^{\prime} 22^{\prime \prime} \mathrm{E}$, alt. $1900 \mathrm{~m}$, open woodland habitats with Quercus macranthera in the gorge of Dzhoakhor river, on bark of Q. macranthera, 07.07.2018, leg. J. Vondrak (DAG 1139).

\section{REFERENCES}

Akayev, B. A. (ed.), Atayev, Z. V., Gadzhiev, B. S., Gadzhieva, Z. Kh., Ganiyev, M. I., Gasanguseinova, M. G., Zalibekov, Z. M., Ismailov, Sh. I., Kasparov, S. A., Lepekhina, A. A., Masayev, V. O., Rabadanov, R. M., Solovyov, D. V., Surmachevskiy, V. I., Tagirov, B. D. \& Eldarov, E. M. 1996. Physical geography of Dagestan. Makhachkala, 382 pp. (In Russian).

Alverdiyeva, S. M. \& Aghayeva, D. N. 2015. Lichens from Absheron Peninsula of Azerbaijan. Novitates Systematicae Plantarum Non Vascularium 49: 219-230.

Candan, M. 2016. Lichens and Lichenicolous fungi of Akdag Natural Park (Afyon-Denizli) in Turkey. Biological Diversity and Conservation 9(3): 198-203.

Esslinger, T. L. 2007. A synopsis of the North American species of Anaptychia (Physciaceae). The Bryologist 110(4): 788-797. https://doi. org/10.1639/0007-2745(2007)110[788:ASOTN A]2.0.CO;2

Gasparyan, A. \& Sipman, H. J. M. 2013. New lichen records from Armenia. Mycotaxon 123: 491-492. https: / / doi.org/10.5248/123.491

Gasparyan, A. \& Sipman, H. J. M. 2016. The epiphytic lichenized fungi in Armenia: Diversity and conservation. Phytotaxa. 281(1): 1-68. https://doi. org/10.11646/phytotaxa.281.1.1

Hernández-Padrón, C. E. \& Pérez-Vargas, I. 2010. Lichenes, Lichenicolous Fungi. In: Arechavaleta, M., Rodriguez, S., Zurita, N. \& García, A. (eds.). Lista de especies silvestres de Canarias. Hongos, plantas y animales terrestres. 2009. Gobierno de Canarias. Pp. 71-105.
Huneck, S., Poelt, J., Ahti, T., Vitikainen, O. \& Cogt, U. 1987. Zur Verbreitung und Chemie von Flechten der Mongolischen Volksrepublik. II. Ergebnisse der Mongolisch-Deutschen Botanischen Expeditionen seit 1962 Nr. 177. Nova Hedwigia 44: 189-213.

Kondratyuk, S., Lőkös, L., Tschabanenko, S., Moniri, M. H., Farkas, E., Wang, X., Oh, S.-O. \& Hur, J.-S. 2016. New and noteworthy lichen-forming and lichenicolous fungi: 5. Acta Botanica Hungarica 58(3-4): 319-396. https://doi.org/10.1556/ ABot.55.2013.3-4.9

Kudratov, I. \& Mayrhofer, H. 2002. Catalogue of the lichenized and lichenicolous fungi of Tajikistan. Herzogia 15: 91-128.

Moniri, M. H., Gromakova, A. B., Lőkös L. \& Kondratyuk S. Y. 2017. New members of the Megasporaceae (Pertusariales, lichen-forming Ascomycota): Megaspora iranica spec. nova and Oxneriaria gen. nova. Acta Botanica Hungarica 59(3-4): 343-370. https://doi.org/10.1556/034.59.2017.3-4.5

Pišút, I. 1978. Neue und interessante Flechten aus Sowjet-Zentralasien. Preslia (Praha) 50: 193-197.

Poelt, J. \& Wirth, V. 1968. Flechten aus dem nordostlichen Afghanistan gesammelt von H. Roemer in Rahmen der Deutschen Wakhan-Expedition 1964. Mitteilungen der Botanischen Staatssammlung München 7: 219-261.

Seaward, M. R. D., Sipman, H. J. M., Schultz, M., Maassoumi, A. A., Haji Moniri Anbaran, M. \& Sohrabi, M. 2004. A preliminary lichen checklist for Iran. Willdenowia 34: 543-576. https://doi. org/10.3372/wi.34.34218

Steiner, M. \& Poelt, J. 1986. Flechten aus Afghanistan - II. Die Laub- und Strauchflechten. Nova Hedwigia 42: 213-236.

Szatala, Ö. 1940. Lichenes. In: Rechinger, K. H., Baumgärtner, J., Petrak, F. \& Szatala, Ö. 1939. Ergebnisse einer botanischen Reise nach dem Iran, 1937. Annalen des Naturhistorischen Museums in Wien 50: 410-536.

Takhtajan, A. L. 1986. Floristic Regions of the World. Berkeley, University of California. 544 pp.

Urbanavichus, G. P. 2008. Genus Anaptychia Körb. In: Handbook of the lichens of Russia. 10. Agyriaceae - Tricholomataceae. (In Russian). St.-Petersburg, Nauka. Pp. 134-149.

Valadbeigi, T., Nordin, A. \& Tibell, L. 2011. Megaspora rimisorediata (Pertusariales, Megasporaceae), a new sorediate species from Iran and its affinities with Aspicilia sensu lato. Lichenologist 43(4): 285-291. https://doi.org/10.1017/ S0024282911000211 